\title{
JAPAN'S EFFORTS TO MAINTAIN ITS PRESENCE IN INDONESIA THROUGH POPULAR CULTURE FROM 2011-2012¹
}

\author{
Yusy Widarahesty
}

\begin{abstract}
“Cute Power! Asia is in love with Japan's pop culture... Everybody loves Japan!..Ask anybody in Asia: Western-style cool is out. Everything Japanese is in- and oh, so cute!" 2 (Newsweek Asia, 8 November 1999)
\end{abstract}

\section{Approaches}

To examine Japan's efforts to maintain its presence in Indonesia through popular culture (A Study about Japan's Foreign Policy from 2011-2012), the researcher employed theories of cultural studies of popular culture and soft power. Some of the main concepts used to provide an explanation of existing problems are based on the postcolonial framework by using the frame of "flying geese." Cultural studies is a discursive formation, that is a bunch of (or formations) initiative whose imagery and practices provide ways to talk about, provide forms of knowledge and comportment associated with a topic, social activity or area of certain institutions in society. ${ }^{3}$ Bannet offers a concept that he terms as "elements definition" (elements of definition) of cultural studies, which is described as follows:

Cultural studies is an interdisciplinary field which selectively taking different perspectives from other disciplines to examine the relationships between culture and politics; (2) cultural studies is interested in all sorts of forms, and classification system that allows implementations of values, beliefs, competences, routines of life and behavior characteristic forms that become habits in a population; (3) cultural studies exploring various kinds of power include gender, race, class, colonialism, and others. Cultural studies aims to study how these forms of this power are related, as well as develop ways to understand the culture and the powers can be used by those who became an agent in an effort to make a change; (4) the main institution of cultural studies is an institution of higher education, and in this case cultural studies have in common with these areas of academic discipline. Nevertheless, cultural studies attempt to establish a connection outside the academic realm with socio-political movements, the workers in cultural institutions, as well as cultural management. ${ }^{4}$

Based on Bennet's explanation of some of the elements of the definition in cultural studies, it is clear that cultural studies are closely related to various disciplines. In this study, cultural studies is used as the main approach because the problem raised is

\footnotetext{
This work was supported by LP2M Universitas Al Azhar Indonesia (Institute For Research and Community Services Al Azhar Indonesia University).

2 Koichi Iwabuchi, Popular Culture, Globalization and Japan: Japanese Popular Culture and Postcolonial Desire for Asia, Routledge, New York, 2006, p15.

3 S.Hall (ed.), Representation, London \& Thousand Oaks, California, Sage, 1997, p 6.

4 S Hall (ed)., Representation, London \& Thousand Oaks, California, Sage, 1997, pp. 8-9.
} 
closely related to concepts that are included in the scope of cultural studies, which is popular culture.

\section{Popular Culture}

In general, John Storey summarizes several definitions of popular culture into six definitions:

An obvious starting point in any attempt to define popular culture is to say that popular culture is simply culture that is widely favored or well liked by many people. [...] what is clear is that any definition of popular culture must include a quantitative dimension. The popular of popular culture would seem to demand it. However, a quantitative index is not enough to provide an adequate definition of popular culture. [...]

A second way of defining popular culture is to suggest that it is the culture that is left over after we have decided what high culture is. Popular culture, in this definition, is a residual category, there to accommodate texts and practices that fail to meet the required standards to qualify as high culture. In other words, it is a definition of popular culture as inferior culture. [...]

A third way of defining popular culture is as 'mass culture'. The first point that those who refer to popular culture as mass culture want to establish is that popular culture is a hopelessly commercial culture. It is mass-produced for mass consumption. [...] A fourth definition contends that popular culture is the culture that originates from 'the people'. According to this definition, the term should only be used to indicate an 'authentic' culture of 'the people'. This is popular culture as folk culture: a culture of the people for the people.

A fifth definition of popular culture, then, is one that draws on the political analysis of the Italian Marxist Antonio Gramsci, particularly on his development of the concept of hegemony. [...] Those using this approach see popular culture as a site of struggle between the 'resistance' of subordinate groups and the forces of 'incorporation' operating in the interests of dominant groups. [...]

A sixth definition of popular culture is one informed by recent thinking around the debate on postmodernism. [...] The main point to insist on here is the claim that postmodernism culture is a culture that no longer recognizes the distinction between high and popular culture. $[. . .]^{5}$

Richard Maltby also explains that:

[...] popular culture provides 'escapism that is not an escape from or to anywhere, but an escape of our utopian selves. [...] If it is the crime of popular culture that it has taken our dreams and packaged them and sold them back to us, it is also the achievement of popular culture that it has brought us more and more varied dreams than we could otherwise ever have known. ${ }^{6}$

Therefore, the alignment of text in cultural studies espoused by Bertolt Brecht in his book "On Theatre" explains that:

5 John Storey, Cultural Theory and Popular Culture (Fifth Edition), London, PEARSON Longman, 2009, pp 5-12.

6 Richard Maltby, (ed.), Dreams for Sale: Popular Culture in the 20th Century, London, Harrap, $1989, \mathrm{p} 14$. 
Good or bad, a play always includes an image of the world. [...] There is no play and no theatrical performance which does not in some way affect the dispositions and conceptions of the audience. Art is never without consequences. ${ }^{7}$

One thing that needs to be underlined is the ability of cultural texts to affect the perspective of audiences. Brecht's "Theatre" observes that the nature of art always has its own consequences when consumed. Viewed from the perspective of the audience, the various texts become part of popular culture products such as television dramas, movies, and pop music. Through its packaging, popular culture has the power to influence or even change the mindset of viewers in the manner in which they view things or social phenomena.

\section{Soft Power}

Soft power is a term used by Joseph S Nye to describe the invisible elements of nonmilitary, non-economic strength of a country; it is the cultural influence and ideological appeal. Based on the soft power definition above, it can be said that the spread of Japanese popular culture in East and Southeast Asia created much excitement among Japanese journalists, industry players, government officials and academics; this is because they found Japanese popular culture useful in the mission to enhance Japan's cultural diplomacy. In this context, the Japanese government has been interested in promoting the export of its TV programs and popular culture to other Asian regions. Iwabuchi also explained that the beneficial facets of the Japanese popular culture were able to help Japan's reconciliation with its neighboring countries with reference to political and diplomatic matters. ${ }^{8}$ Hence, the Japanese popular culture plays an important role in portraying a positive image of Japan in the world.

\section{Postcolonial Framework}

\section{Picture I}

Flying Geese

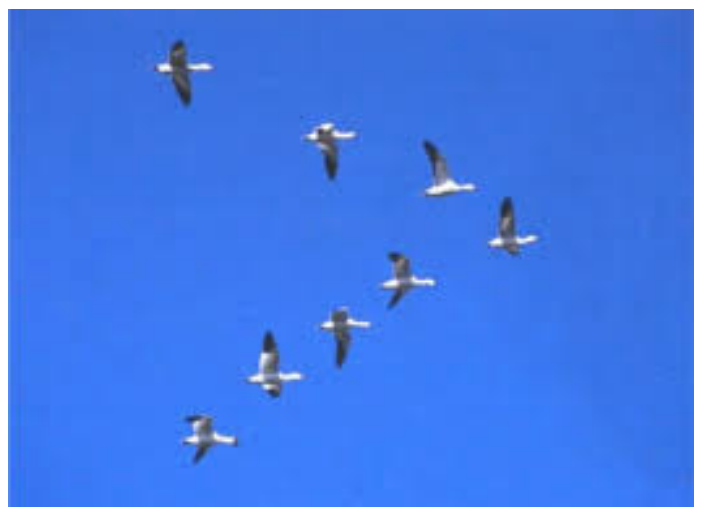

Source: Flying geese, http:// www. Aerospaceweb.org, assessed September 2013

Bertolt Brecht, On Theatre, London, Methuen, 1978, pp. 150-151.

8 Koichi Iwabuchi, Popular Culture, Globalization and Japan: Japanese Popular Culture and Postcolonial Desire for Asia, 2006. 
The phrase "flying geese (FG) pattern of development" was coined originally by Kaname Akamatsu in Japanese articles published in the 1930s. Presented to the world after World War II, in 1961, and in 1962, many articles depicting the FG were published in English. The FG pattern represented a special kind of dynamism. In the Pacific region, the United States was the first to become a developed country. Beginning in the late 19th century, Japan began to play catch-up in the following areas in this particular order: nondurable consumer goods, durable consumer goods, and capital goods sectors. Today, the Asian newly industrialized countries and the ASEAN nations are following in Japan's footsteps. ${ }^{9}$

As a leading modern country, Japan is recognized as a role model in many aspects for Asian countries. The argument that Japan and Asia share the common experience of "hybrid" modernization has been easily developed into the assertion that Japan's experience can be a model for other Asian countries' emulation. This is a position that presumes Japan is a non-Western nation that has successfully assimilated Western civilization and traditional culture. ${ }^{10}$

Here, the FG pattern can be seen in the aspect of ideology and culture. From the framework of a postcolonial country, South Korea is a prime example of one of the countries that had long banned the entry of Japan's popular culture. This is attributed to the historical mindset on the relationship between Japan and Korea; the bad memories of Japanese colonialism have not been forgotten by Korea. The 2002 soccer World Cup marked the opening of the South Korean market to Japan and other Asian countries such as China. As a result, this saw the beginning of Korean popular (KPOP) boom (hallyu) penetrate into these countries.

It is envisaged that in the FG pattern of formation that forms the letter $\mathrm{V}$, the leader at the front is Japan and it leads other countries' economies in Asia. In this study, the FG pattern is also seen in terms of pioneering popular culture in Asia. Japanese popular culture (JPOP) used to be a big hit in the Asian market, but the latest phenomenon is KPOP. KPOP is now in the spotlight and has overtaken JPOP in reflecting East Asian culture. As a developed country, South Korea has learnt the manner in which Japan successfully built its cultural image in all regions of Asia to Europe. Thus, it can be said that popular culture is a cultural element that cannot be underestimated in its significance to a country's soft power. Based on the concept of flying geese, Japan's position as the leader of other Asian countries is under threat; it is faced with strong competition from other countries that wish to gain influence as a leader in Asia. From the FG pattern, it can be seen that in the past, American culture dominated world culture, including Asia. The American culture dominance was then replaced by Japan, but its position is slowly diminishing. The Korean wave now has become the new phenomenon that is trying to offer an alternative of what Asian culture should look like, which in the past had been dominated by Japanese popular culture. When observed, the phenomenon of Korean wave that swept the world, including Indonesia, it can be argued that Japan responded to the Korean wave phenomenon by trying to re-boost the influence of the Japanese popular culture, especially in Indonesia in an effort to maintain its influence.

9 Flying Geese Theory, http://www.grips.ac.jp/forum/module/prsp/FGeese.htm, assessed August 2013.

10 Koichi Iwabuchi, Popular Culture, Globalization and Japan: Japanese Popular Culture and Postcolonial Desire for Asia, 2006. 


\section{Japanese Popular (JPOP) Culture History}

Japan had great significance in terms of expanding popular culture from "the East" in the 1980s to 1990s. From the 1980s to 1990s, Japan was a strong representation of the culture of East Asia that was capable of competing internationally along with the "Western" culture represented by the United States and Europe (especially the United Kingdom). The Japanese popular culture was an alternative to the culture of "the West" as expressed by Otmazgin:

Japanese-made media productions have additionally served as an example and a model for media-collaborated productions in East Asia, providing an alternative to American models. In East Asia of today, many of the music, television, comic books, and animation products might incorporate a mix of locally drawn motifs and languages, while the format they are shaped in is Japanese. ${ }^{11}$

There are also arguments that Japan has this privilege because it is the first East Asian country to modernize or develop rapidly through westernization and economic development. ${ }^{12}$ This opinion assumes that Japan's relations with the Western world, driven by phenomenal economic progress, namely "the Japanese Miracle", enabled Japan to have a huge potential in terms of spreading its culture and international influence in the world at that time. This statement makes sense, considering the reception of the market in terms of international pop culture; for instance, Japan had the largest music sales market in Asia and the second largest in the world between 2004 and 2009 (see Chart 1). ${ }^{13}$ On top of that, Japan became the number one music market in the world in 2010.

Chart 1.

II. Global Music Recording Sales (per million United States dollars) - 2004 2005
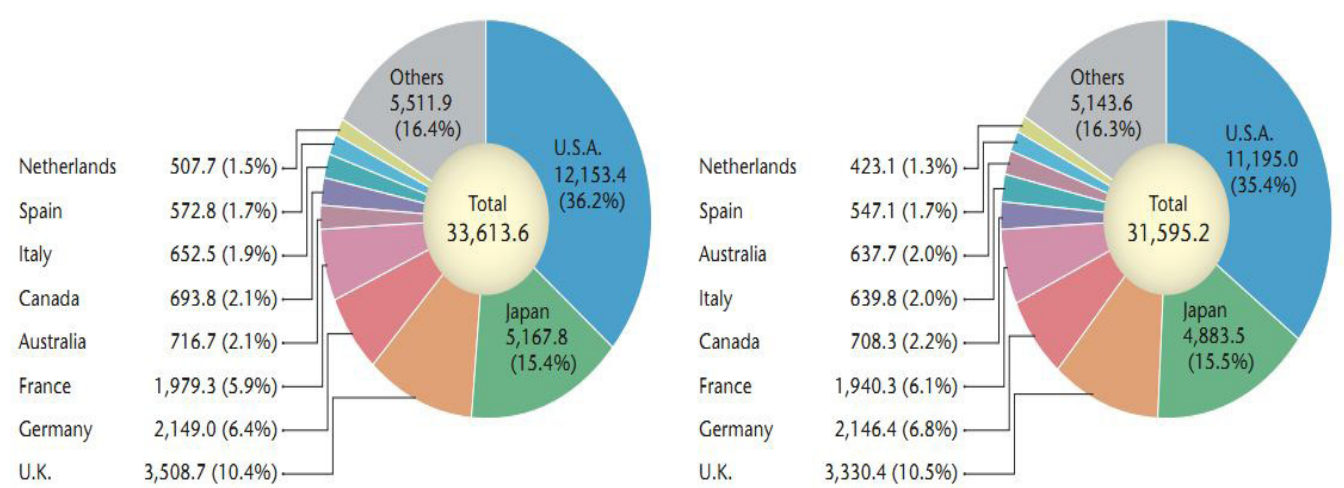

11 Chua Beng Huat dan Koichi Iwabuchi, ed., East Asian Pop Culture: Analyzing the Korean Wave, Hong Kong, Hong Kong University Press, 2008, p 509.

12 Kim, Ju Young, or Jonghoe Yang, "The Korean Wave (Hallyu) in East Asia: A Comparison of Chinese, Japanese, and Taiwanese Audiences Who Watch Korean TV Dramas", Development and Society, Vol. 41, No.1, June, 2012, p 104.

13 Recording Industry Association of Japan (RIAJ), Statistic Trends: The Recording Industry in Japan 2011, Japan, RIAJ, 2011, p 23. 

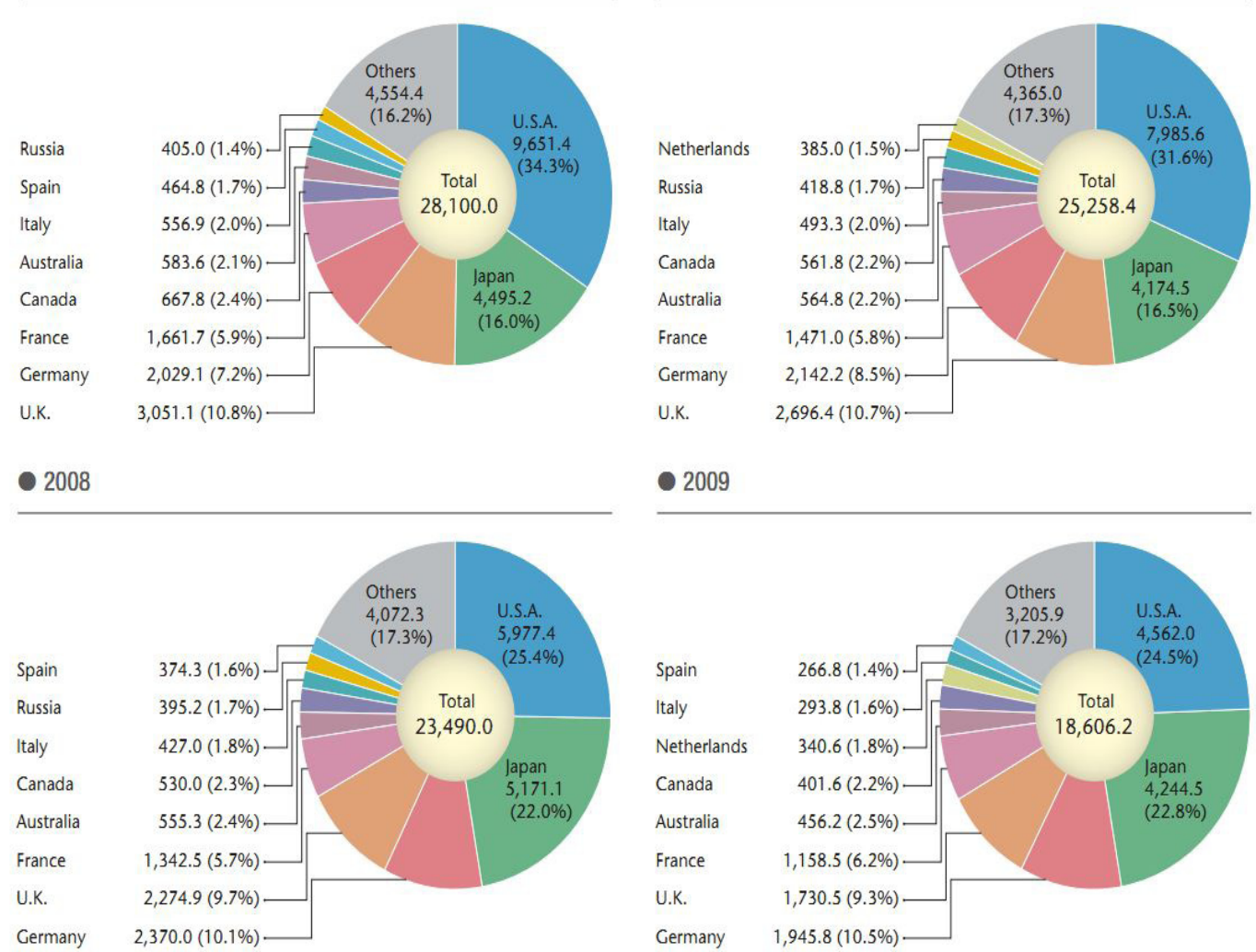

Source: “Japan, US Top Global Recorded Music Sales”, Manila Bulletin. http://ph.news.yahoo.com/japan-ustop-global-recorded-music-sales-080346271.html, assessed 8 March 2013

In short, the digital music market is worth billions of U.S. dollars annually. Japan provides a very good market opportunity for artists, bands, musicians, and record labels to get digital distribution via the mobile Internet market and the Japanese market. ${ }^{14}$ Thus, with economic strength and good relations with the West, Japan was awarded the privilege as a "model" Eastern culture and the industry became important in global cultural industry. Japan's popular culture increased in the 1970's era in Indonesia. Moreover, soap operas such as "Oshin", anime (Doraemon), Sailor Moon, and Tokyo love stories, improved the image of Japan in Asian countries, especially Indonesia.

${ }^{14}$ Furthermore, it should be understood that the mobile phone market in Japan is very prevalent along with advances in mobile phone technology and culture. $80 \%$ of digital music sales in Japan are done via mobile phone (keitai). Hence, digital distribution in the Japanese mobile phone market is an aspect that cannot be ignored. Sourced from Japanese Market Opportunity for Foreign Music", Japan Internet Communications Service Inc. (JICS) Media. http://japanmusicmarketing. com/about.htm,_assessed 8 March 2013. 


\section{Picture 2 \\ A Popular Drama Series "Oshin"}

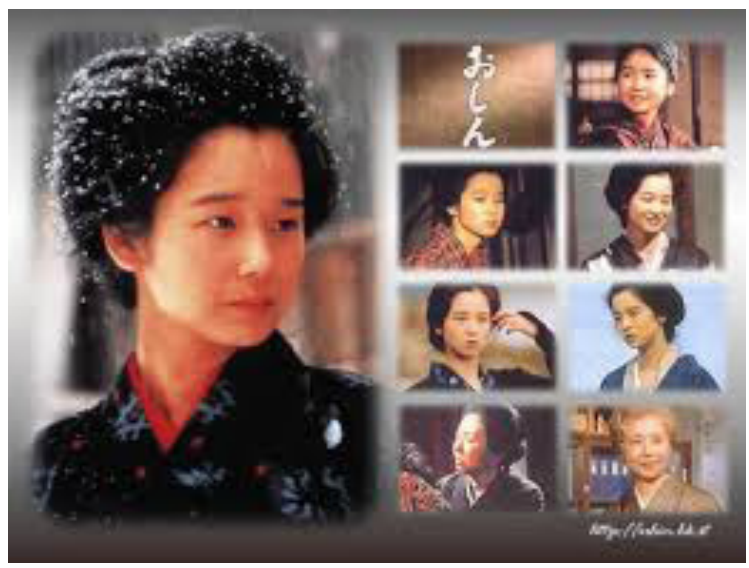

Source: http:// www. entertainment.kompas.com, 2013

In the 1990s, Indonesian society was fascinated by the popular culture portrayed in Japanese comics, cartoon series and dramas. In particular, "Oshin" drama became one of the phenomenal television series in Indonesia. Through its episodes, Indonesian people experienced Japanese culture, history and the routines of Japanese daily lifestyle. Oshin is one proof of the success of Japanese popular culture in Indonesia, which was then followed by Tokyo Love Stories, Black Knight Common Rider, Doraemon cartoons, Candy-Candy and Sailor Moon.

Through the spread of the Japanese popular culture, Japan influenced Asian countries, including Indonesia. Because of Japanese popular culture, people began to be very interested to know more about Japan. A magazine of Japan foundation ${ }^{15}$, stated that while interest in learning Japanese language in the era of the 1970-80s was motivated by economic factor, in the era of the 1990s, it evolved into a cultural motivation equivalent to the explosion of Japanese popular culture in Indonesia. After 2000, Japanese popular culture in Indonesia, particularly in drama and music began to fade as a result of the emergence of Korean wave, which offered an alternative of popular culture as a representation of Asian culture.

\section{Korean Wave "Hallyu” (KPOP)}

The history of the Korean Wave often revolves around the emergence of the term "Korean Wave" itself, i.e. when the term first appeared in 2000 as used by a journalist from China, which represented an increase interest in South Korean products in China, from cars to kimchi (Korean style vegetable preserve). However, the main increase in interest was due to the export of popular culture through Korean television series or K-Dramas, before the expansion to K-POP.

Korean Wave or Hallyu is quite visible in TV dramas, movies, pop music and other forms of entertainment. Glamorous trendy music and dances performed by Korean singers "Se7en," "Rain," and "Gangnam Style" as 2012 K-pop single sung by Korea's rapper, Park Jae Sang, or better known as PSY, drew attention of teenagers to Korea and

\footnotetext{
15 The Japan Foundation, Nuansa, Jakarta, October-November- December edition, 2013, p 22.
} 
Korean pop culture. Furthermore, people now are developing a taste for Korean food. Asians are crazy about Korea's pop culture and diverse entertainment content which are not limited exclusively to popular music but also to television dramas, movies, and video games that are being exported to Indonesia and other countries in Southeast Asia. Since 2000, several private television stations in Indonesia have been competing to show Korean movies and dramas. In fact, several Korean dramas have been successful on Indonesian television screens, such as Winter Sonata, Endless Love and Dae-jang Geum. In addition to Hollywood entertainment, Korean movies and dramas attract many fans in Indonesia in the period between 2005 and 2009. Moreover, Korean pop songs started to penetrate the music industry in Indonesia, either through the internet, MP3s, iPods, tapes, or CDs, all of which are easily found in the record stores in the country. ${ }^{16}$

Few studies have been done, especially by Indonesian researchers, on the background of South Korean export of its culture and how the term "Korean Wave" was coined and took the world by storm. This conclusion was reached by examining the following publications: analyzes about "Korean Wave" by international newspapers such as the New York Times ${ }^{17}$; reports on results of the "Korean Wave," which was published by the Ministry of Culture and Information in South Korea; contemporary Korean-book series such as The Korean Wave: A New Pop Culture Phenomenon (2011), K-Drama: A New TV Genre with Global Appeal (2011) - Korean Culture and series like K-POP: A New Force in Pop Music (2011) and K-Classics: A New Presence on the World's Stage Musical, which only gives a brief analysis of the success of the reception of "Korean Wave" in the form of K-drama Winter Sonata in early $2000^{18}$.

Picture 3.

Winter Sonata

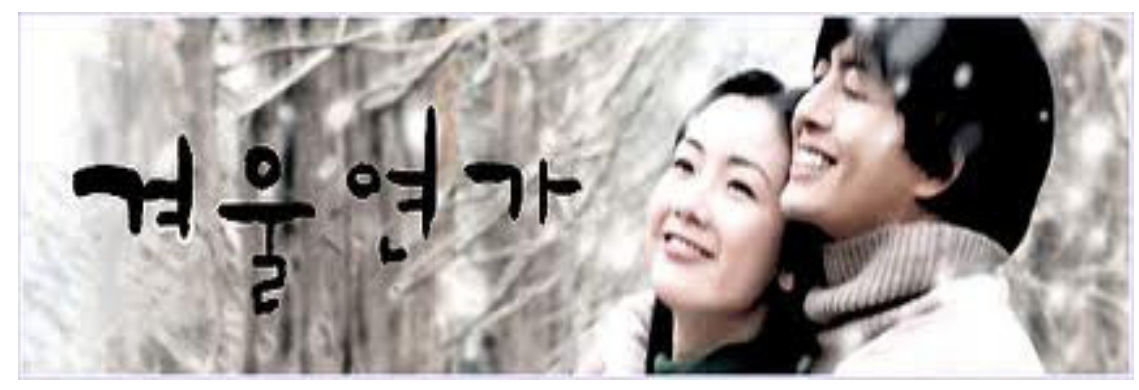

Source: Oshin Drama http:// www.visitkorea.or.id.kr, assessed 9 April 2013

16 Mukhtasar Syamsudin, Hallyu and Indonesia: Hallyu Status in Indonesia and Its Impact, The Culture Cooperation \& Korean Wave (Hallyu) Seminar, Jakarta, 2012, p 3.

17 News in international newspapers about the early emergence of the "Korean Wave" is more of an analysis of the market demand for the phenomenon. One of the earliest news articles about the "Korean Wave," waspublished by the New York Times. Full details of the New York Times article can be found at http:/ / www.nytimes.com/2006/01/02/world/asia/02ihtkorea.html?pagewanted=all\&_r=0, assessed August 2013.

18 This publication is part of the project of the Ministry of Culture and Information South Korea to promote South Korea in Indonesia. The official publication of the results can be accessed at http://www.korea.net/Resources/Publications/About-Korea. 
In the context of bilateral cooperation, the two countries (Indonesia and Korea) have established close cooperation in trade, investment, workforce, tourism, transfer of technology and technical assistance. For the last four decades, the relationship between the two countries has been expanding smoothly and there have been many achievements with mutual benefits.

\section{Japan's Efforts to Maintain its Presence in Indonesia through Popular Culture in 2011-2012}

In the globalization era, culture is an important element in building communication among nations. Therefore, through cultural diplomacy, Japan and Korea have tried to use tactical and strategic approach to gain influence through promoting their cultures followed by political and economic policies. As Joseph Nye said, the invisible nonmilitary and non-economic elements form the strength of a country, which encompass cultural influence and ideological appeal. Therefore, through the pattern of the FG (V formation), Japan as the first leading Asian country, tried to increase the popularity of Japanese pop culture in Indonesia. Thos cultural tool contributed to the awakening of human understanding and motivation in developing cooperation among nations. This effort was an attempt to maintain Japan's presence in the international community, especially in Indonesia. From 2011, Japanese popular culture began to dominate the shows broadcasted by Indonesian television stations. One of the popular stations is JKT48 the Indonesian music idol group, which was formed by a music network from Japan.

\section{Picture 4. \\ JKT 48}
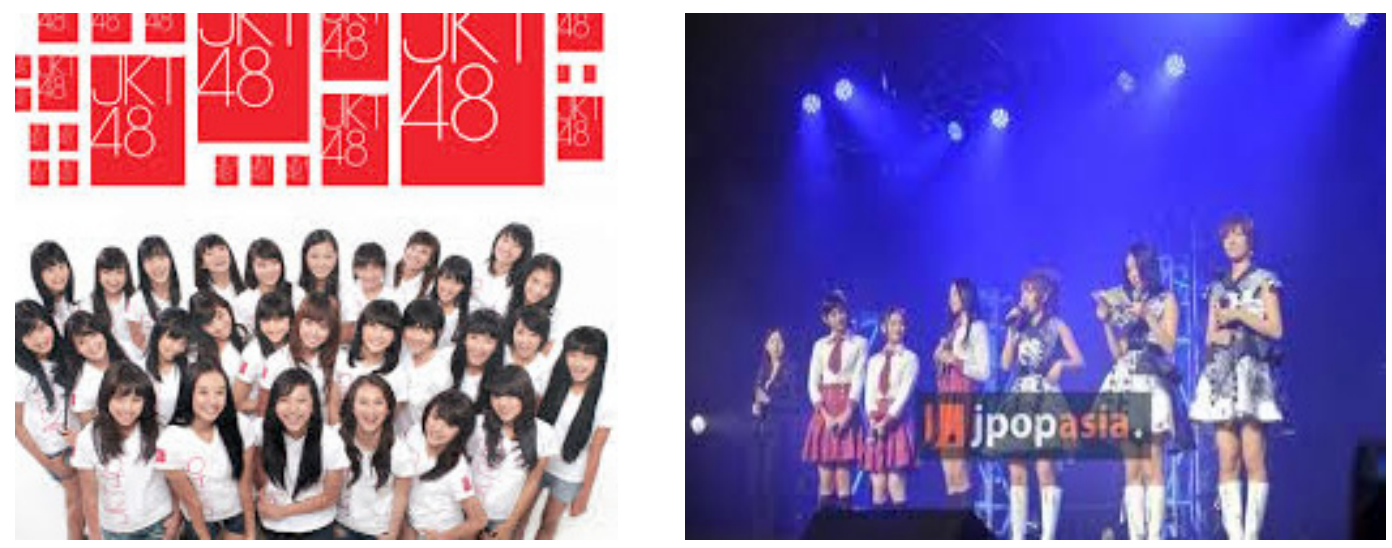

Sources: http:/ / JKT 48,www. antaranews.com, assessed September 2013; http:// JKT 48, www.music.yess.online.com, assessed August 2013

However, it can be argued that the rise of Korean pop culture in Asia, a phenomenon called the Korean wave, has significantly undermined Japan's position in the regional cultural flow. The Japanese cultural superiority in other Asian nations 
has been displaced..$^{19}$ Hence, from 2011 until today, it has become vital for Japan to reboost the superiority of Japanese pop culture to the level of its heyday, especially in Indonesia. For example, JKT48 as the first idol group in Indonesia now has numerous shows on Indonesian private television channels like RCTI, Trans 7 and many more. Several programs are shown to promote Japanese culture such as JKT48 missions, JKT 48 story and many others.

\section{Conclusion}

For Japan, maintaining good relations with Indonesia and having a strong presence in the country is crucial. The cooperation between Japan and Indonesia has been ongoing since 1945 in several aspects, including trade, economy, education, and culture. According to the Japan Foundation, it is estimated that 3.6 million people are learning the Japanese language outside Japan; in Indonesia, around 800,000 Indonesian students are currently learning the Japanese language. Japanese language is the third most learned language in the world after Korean and Chinese..$^{20}$

From the concept of "idol you can meet every day," JKT 48 was formed by Akimoto Yasushi, the founder of AKB 48 in Japan. The idea was to introduce the concept of a Japanese idol group in Indonesia. JKT 48 was formed in September 2011, and Akimoto called JKT 48 the "first overseas project of 48 families" outside Japan. Apart from showing its programs on Indonesian private television stations, JKT 48 also became the commercial artist for many Japanese products such as Pocari Sweat, Laurier, Yamaha Mio J, Biore, Pocky, and New Honda Brio. JKT 48 which also has two Japanese members, Aki Takajiyo and Haruka Nakagawa has aided these brands to prosper in Indonesia. ${ }^{21}$

Through popular culture, Japan tries to maintain its presence in Indonesia, especially after Korean Wave emerged as the new phenomenon in the entertainment world, including in Indonesia. Both Japan and Korea are competing fiercely to exert as much influence on Indonesia through various forms of pop culture from drama to music. For Japan, it is currently interested in promoting Japanese popular culture to improve not just its reputation but also to strengthen its presence in Asia (as the $\mathrm{V}$ formation in FG pattern). As mentioned before, Bertolt Brecht's reasons popular culture has a role to play in a global world and that "Art is never without consequences."

19 Koichi Iwabuchi, Popular Culture, Globalization and Japan; Japanese Popular Culture and Postcolonial Desire For Asia, Routldge Taylor and Francis Group, New York, p 31.

20 Veeramalla Anjaiah, Hallyu And Indonesia; Some Thoughts on Hallyu or The Korean Wave in Indonesia. The Culture Cooperation \& Korean Wave (Hallyu) Seminar, Jakarta, 2012, p 3.

${ }^{21} \mathrm{http} / / \mathrm{jkt}$ 48fanblog.blogspot.com/p/apa-itu-jkt48.html.September 2013. 